\title{
The Effectiveness of Piper betel L. Leaf Extract as a Natural Electric Mosquito
}

\author{
Safrida Safrida ${ }^{1, *}$ Fitrah Asma Ulhusna ${ }^{2}$ \\ ${ }^{1,2}$ Biology Education Program, Faculty of Teacher Training and Education, Syiah Kuala University, \\ Darussalam-Banda Aceh 23111, (0651) 7551407 \\ "Corresponding author. Email: saf rida@unsyiah.ac.id
}

\begin{abstract}
Mosquitoes are known as insects that interfere with comfort. Mosquitoes are also known as vectors or transmitters of several types of dangerous and deadly diseases for humans, one of which is dengue fever. Therefore, an alternative is needed to reduce this species. The alternative that can be done is by providing vegetable insecticides. Betel leaf has the potential to be used as a base for making plant-based insecticides that are environmentally friendly because they contain chemical compounds in the form of phenols and derivatives such as chavikol and eugenol, alkaloids, tannins, flavonoids, saponins and essential oils. This study aims to determine the concentration of betel leaf extract (Piper betel L.) which is effective for killing mosquitoes. This study used an experimental method using a completely randomized design (CRD) with 6 treatments and 4 replications, namely KN as negative control group, KP as control positive (100\% HIT brand liquid), P1 25\% extract, P2 50\% extract, P3 75\% extract, and P4 100\% extract. The number of dead mosquitoes (mortality) were observed after 1 hour of treatment. Data were analyzed using variance analysis (ANAVA). The results of this study were the administration of various concentrations of betel leaf extract (Piper betel L.) significantly ( $p$ $<0.05)$ to kill mosquitoes. The greatest frequency of mosquito mortality was found at the P4, the highest extract concentration. The conclusion of this study is that betel leaf extract for 1 hour had a significant effect on mosquito mortality.
\end{abstract}

Keywords: Betel leaf, extract, mortality, mosquito

\section{INTRODUCTION}

Mosquitoes are insects that cause many problems for humans. The diseases caused by mosquitoes deploy over 2.5 billion populations throughout the world [1]. Mosquitoes are vectors or transmitters of several types of dangerous and deadly diseases to humans, such as dengue fever, malaria, and chikungunya $[2,3]$

Dengue Hemorrhagic Fever (DHF) is a public health problem that is increasingly spreading because the morbidity and population density increased. Dengue fever (DF) cases are currently being reported from 129 countries from the WHO regions of the Americas, South-East Asia, Africa, and the Western Pacific [4]. In Indonesia, the number of dengue cases in 2015 was reported at 50,775 / 100,000 population. In 2016 there was an increase in dengue cases with 204,171 patients, with 1,598 deaths. Meanwhile, in
2017 the number of dengue cases has decreased with 68,407 patients, with 493 died [5].

Currently, there is a very urgent need to manage mosquito vectors. Nowadays, various commercially formulated chemical and biological repellents are available in the market, but the use of chemicals can trigger mosquito resistance and ecological imbalance [6]. These issues triggered scientist to creating ecofriendly insecticides for mosquito vectors.

Natural products of plant origin contain insecticidal properties. This has attracted the attention of researchers in recent decades. This is one of the alternative mosquito control strategy to eliminate or eradicate the use of chemical pesticides [7].

Betel leaves have a strong pungent and aromatic aroma [8]. Betel leaves widely cultivated in tropical and subtropical countries so they being long used by humans [9]. It contains chavicol, phenols, chavibetol, 
cadinene and hydroxychavicol [10]. The crude volatile oil of betel leaves has been shown to have insecticidal properties $[9,11]$.

This research uses betel leaf as a natural insecticide. The use of betel leaf extract to eradicate mosquitoes needs to be studied further. Betel leaf extract is made in liquid form which is more comfortable and easier to use. This study aims to determine the concentration of betel leaf extract which is effective for killing mosquitoes.

\section{MATERIALS AND METHOD}

\subsection{Preparation of Betel Leaves Extract}

Betel leaves were collected from Limpok district. The leaves were washed and air-dried, then finely ground using a blender. Furthermore, the dry powder betel leaves were macerated in $96 \%$ ethanol with a ratio of 1:20 for 2 day. The extract was filtered until it was separated from the residue. The filtrate was collected and evaporated using a rotary evaporator to obtain pure $100 \%$ concentration extract.

\subsection{Application of Betel Leaves Extract to the Animal}

This study used completely randomized design with 6 treatments and 4 replications. $\mathrm{KN}$ as the negative control group, $\mathrm{KP}$ as positive control group were given HIT brand liquid, P1 25\% extract, P2 $50 \%$ extract, P3 75\% extract, and P4 100\% extract. The treatment was given for 1 hours. Mosquito mortality was calculated following:

Mort $=\frac{\text { The number of dead mosquito }}{\text { The number of tested mosquito }} \times 100 \%$

\subsection{Data Analysis}

The effect of betel leaves extract on mosquito mortality was analyzed using one-way Analysis of Variance (ANOVA) with $\mathrm{P}<0.05$. Post hoc analysis conducted with Duncan's Test.

\section{RESULT AND DISCUSSIONS}

The result showed that giving betel leaves extract increased mosquito mortality. Figure 1 showed that the greatest frequency of mosquito mortality is at the highest extract concentration. By giving $100 \%$ betel leaves extract can reduce $90 \%$ mosquito. This result is the same as the positive control.

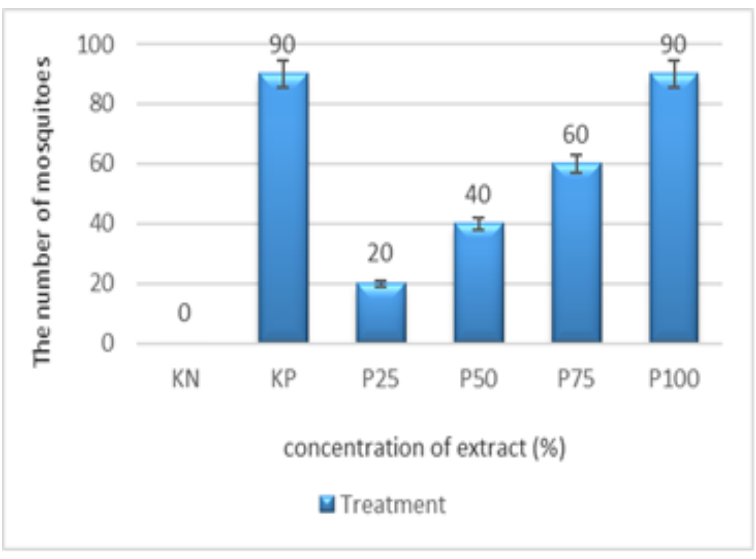

Figure 1 Mosquito mortality after treatment

Plant derivatives have highly active compounds for control of various arthropod pests and vectors [12]. Betel leaf contains phenolic compounds with derivatives such as chavicol, alkaloids, saponins, flavonoids, and essential oils [13]. Chavicol can inhibit the acetylcholinesterase enzyme in larvae so that the hydrolysis of acetylcholine into acetate and choline will be disrupted. This causes accumulation of acetylcholine which results in an unsustainable nerve impulse [14].

Alkaloids will inhibit the enzyme that acts on cAMP metabolism in signal transduction so that the metabolic process is disrupted. The saponin content in betel leaf extract can act as a poison. Saponins are thought to able to diffuse from the outer cuticle layer through the deeper layer to the hemolymph, follow the hemolymph flow, and spread to all parts of the larva's body, causing damage to the larvae cells. The derivative of the flavonoid, namely rotenone, is thought to have larvicidal properties. Rotenone works as a respiratory poison by inhibiting respiratory enzymes, between coenzyme Q (respiratory coenzyme responsible for carrying electrons in the electron transport chain) and NAD + (a coenzyme involved in oxidation and reduction in metabolic processes) resulting in failure of respiratory function. Tannins can inhibit the work of enzymes and remove substrates (proteins), causing disrupted cellular metabolic processes [15]. The betel leaves essential oils are thought to have toxicity and repellent activity for Ae. Aegypti, 3,5-di-tert-butyl-4hydroxybenzaldehyde and -7(11)-en-4-ol compound shows their potential role in causing insect mortality [16]. 
The administration of betel leaf extract with 1hour duration also shows a high mosquito mortality rate. This indicates that the mosquito mortality rate increases along with the increase of durations and concentrations of the extract. The aromatic odor of the essential oil, vaporize that enters the tracheal system, is reported to cause irritation and push the mosquito to leave the treated area. [17]. Other repellency studies also have been reported that the essential oil extracted from several plant species shows high repellent activity against dengue vectors [18].

\section{CONCLUSION}

This study conclude that betel leaves extract can reduce the mosquito mortality. The highest concentration of betel extract is the best candidate as a natural materials or eco-friendly insecticides for electric mosquito's repellent.

\section{REFERENCES}

[1] World Health Organization, A global brief on vector-borne diseases, WHO Press, 2014.

[2] R. Herawati, Ekstrak Daun Sirih (Piper betle L.) sebagai Insektisida Nabati Untuk Membasmi Larva Nyamuk Aedes aegypti L., Doctoral dissertation, UAJY Press, 2009. [In Bahasa Indonesia]

[3] A. Thanigaivel, M.P.C Kanagaraj, K. Sengodan, V.S. Prabhakaran, A. Ponsankar, H. Sivanesh, V.S. Rajab, N.S. Sundar, K.R. Narayanan, S.S. Nathan, Toxic effect of essential oil and its compounds isolated from Sphaeranthus amaranthoides Burm F. against dengue mosquito vector Aedes aegypti Linn, Pesticide Biochemistry and Physiology 160 (2019) 163170.

DOI:

https://doi.org/10.1016/j.pestbp.2019.08.006

[4] O.J. Brady, P.W. Gething, S. Bhatt, J.P. Messina, J.S. Brownstein, A.G. Hoen, Refining the global spatial limits of dengue virus transmission by evidence-based consensus, Plos Neglected Tropical Diseases. 6(8) (2012) 1760. DOI:

https://doi.org/10.1371/journal.pntd.0001760

[5] Kementerian Kesehatan Republik Indonesia, Pusat Data Dan Informasi Kementerian Kesehatan RI: Situasi Penyakit Demam
Berdarah di Indonesia Tahun 2017, Kemkes Press, 2018. [In Bahasa Indonesia]

[6] H. Ranson, R. N'Guessan, J. Lines, N. Moiroux, Z. Nkuni, V. Corbel, Pyrethroid resistance in African anopheline mosquitoes: what are the implications for malaria control?, Trends in Parasitology 27 (2) (2011) 91-98. DOI: https://doi.org/10.1016/j.pt.2010.08.004

[7] K. Kalaivani, S. Senthil-Nathan, A.G. Murugesan, Biological activity of selected Lamiaceae and Zingiberaceae plant essential oils agains he dengue vector Aedes aegypti L. (Diptera: Culicidae), Parasitology Research 110(3) (2012) 1261-1268. DOI: https://doi.org/10.1007/s00436-011-2623-X

[8] M. Wirotesangthong, N. Inagaki, H. Tanaka, W. Thanakijcharoenpath, H. Nagai, Inhibitory effects of Piper betle on production of allergic mediators by bone marrowderived mast cells and lung epithelial cells, International Immunopharmacology 8(3) (2008) 453-457. DOI:

https://doi.org/10.1016/j.intimp.2007.11.005

[9] W.T.S. Dammini-Premachandra, H. Mampitiyarachchi, L. Ebssa, Nematotoxic potential of betel (Piper betle L.) (piperaceae) leaf, Crop Protection 65 (2014) 1-5. DOI: https://doi.org/10.1016/j.cropro.2014.06.004

[10] M. Singh, S. Shakya, V.K. Soni, A. Dangi, N. Kumar, S. Bhattacharya, The n-hexane and chloroform fractions of Piper betle L. trigger different arms of immune responses in BALB/c mice and exhibit antifilarial activity against human lymphatic filarid Brugia malayi, International Immunopharmacology 9(6) (2009) 716-728.

DOI: https://doi.org/10.1016/j.intimp.2009.02.012

[11] S. Mohottalage, R. Tabacchi, P.M. Guerin, Components from Sri Lankan Piper betle L. leaf oil and their analogues showing toxicity against the housefly, Musca domestica, Flavour and Fragrance Journal 22(2) (2007) 130-138. DOI: https://doi.org/10.1002/ffj.1770

[12] S. Senthil-Nathan, Physiological and biochemical effect of Neem and other Meliaceae plants secondary metabolites against Lepidopteran insects, Frontiers in Physiology 4(359) (2013) 1-17. DOI: https://doi.org/10.3389/fphys.2013.00359 
[13] D. Pradhan, K.A. Suri, D.K. Pradhan, P. Biswasroy, Golden heart of the nature: Piper betle L., Journal of Pharmacognosy and Phytochemistry 1(6) (2013) 147-67.

[14] S. M. Valles, P. G. Koehle, Pests in and around the Southern Home: Insecticides Used in the Urban Environment: Mode of Action, IFAS Extension, 2011.

[15] M. Kaihena, V. Lalihatu, M. Nindatu. Efektivitas Ekstrak Etanol Daun Sirih (Piper betle L.) Terhadap Mortalitas Larva Nyamuk Anopheles Sp. dan Culex, Jurnal Kedokteran dan Kesehatan Molluca Medica (2011) 88-105. [In Bahasa Indonesia]

[16] P. Vasantha-Srinivasan, S. Senthil-Nathan, A. Thanigaivel, E. Edwin, A. Ponsankar, S. SelinRani, N.A. Al-Dhabi, Developmental response of Spodoptera litura Fab. to treatments of crude volatile oil from Piper betle L. and evaluation of toxicity to earthworm, Eudrilus eugeniae Kinb, Chemosphere 155 (2016) 336-347. DOI: https://doi.org/10.1016/j.chemosphere.2016.03.1 $\underline{39}$

[17] D. Champakaew, A. Junkum, U. Chaithong, A. Jitpakdi, D. Riyong, B. Pitasawat, Angelica sinensis (Umbelliferae) with proven repellent properties against Aedes aegypti, the primary dengue fever vector in Thailand, Parasitology Research 114(6) (2015) 2187-2198. DOI: https://doi.org/10.1007/s00436-015-4409-z.

[18] R.M. Gleiser, M.A. Bonino, J.A. Zygadlo, Repellence of essential oils of aromatic plants growing in Argentina against Aedes aegypti (Diptera: Culicidae), Parasitology Research 108
(1)
(2011)
69-78.
DOI:

https://doi.org/10.1007/s00436-010-2042-4. 